\title{
Búfalo Antigo - ou Gabriel e outras orquídeas no bolso
}

\section{Old Buffalo - or Gabriel and Other Orchids in the Pocket}

\author{
Búfalo Viejo - o Gabriel y otras orquídeas en el bolsillo
}

Charles Trocate (Sociedade Editorial iGuana, Brasil)*

https://doi.org/10.22409/poiesis.v22i37.47237

\begin{abstract}
RESUMO: Búfalo Antigo - ou Gabriel e outras orquídeas no bolso, de Charles Trocate, explora com sensibilidade aguda o modo de ser do humano em processo de de-composição em diversos níveis e estados. Transa memórias e lembranças que compõem sua matéria poética, dando a ver o mundo em estranhezas e belezas ao mesmo tempo em que critica, resiste e combate pelos versos as densidades do humano.
\end{abstract}

PALAVRAS-CHAVE: poesia; memória; resistência; combate

\footnotetext{
"Charles Trocate é escritor, filósofo e militante político. Editor da Sociedade Editorial iGuana, é membro da Academia Sul Paraense de Letras. Orcid: https://orcid.org/0000-0003-1812-9219. E-mail: charlestrocate@hotmail.com.
} 
ABSTRACT: Old Buffalo - or Gabriel and Other Orchids in the Pocket, by Charles Trocate, explores with a sharp sensibility the human being in our several levels and stages of (de) composition. Meshes memories and recollections that composes his poetic matter, opening a world of odds and beauties at the same time as criticizes, resists, and fights the human densities through verses.

KEYWORDS: poetry; memory; resistance; combat

RESUMEN: Búfalo Viejo - o Gabriel y otras orquídeas en el bolsillo, de Charles Trocate, explora con aguda sensibilidad la forma de ser del ser humano en proceso de descomposición en muchos niveles y estados. Transita los recuerdos y las memorias que componen su materia poética, dando a ver el mundo en extrañeza y belleza mientras critica, resiste y lucha a través de los versos las densidades del ser humano.

PALABRAS-CLAVE: poesía; memoria; resistencia; combate

Citação recomendada:

TROCATE, Charles. Búfalo Antigo - ou Gabriel e outras orquídeas no bolso. Revista Poiésis, Niterói, v. 22, n. 37, p. 91-104, jan./jun. 2021. [https://doi.org/10.22409/poiesis.v22i37.47237]

\section{(cc) BY-NC-ND}

Este documento é distribuído nos termos da licença Creative Commons Atribuição-NãoComercial 4.0 Internacional (CC-BY-NC) (c) 2021 Charles Trocate 


\section{Búfalo Antigo - ou Gabriel e outras orquídeas no bolso}

envio-te meu amor uma recomendação

faz dos teus ossos

a -guerrilha da estepe-

o cacto daquele solo antigo - que um dia nasceu tua

[ira

ela é o semblante dos que ficaram impacientes!

Bilbao, País Vasco

Novembro de 2019 
o interlocutor questiona meu estilo literário

difícil e lento no

[tempo

sua forma anticonjuntural que não se emociona

com a alegoria que outros chamam de luz-admito

confesso com o defeito que o conceito explicanada tenho a ver com isso

pressinto o som da chuva naquela casa de tábua

vinha do Oeste o rio que me fazia menino

escrevo com a emoção da minha mãe

que me chamava para ler aquelas letras que não sabia imaginar onde sucumbia seu analfabetismo

- era a minha primeira revolta

digo a todos- ela é meu estilo literário depois vieram os livros e aquilo que fica depois da vírgula a luta e um jeito de namorar que se explicam daquela experiência de soprar redemoinhos.

Berlim, Alemanha

Novembro de 2019 
a Grã Bretanha era o império - terminou os dias passando o chapéu em Washington os EUA arruinaram os índios Sioux e explodiram o iluminismo -

a época da consciência seu fim de onde rondam os

[monstros

perdeu-se o bonde e o brinde

e o alfinete da roupa no atelier - o aço em Paris ou em Arcoverde

é faca assassina mata dançando - a

[bailarina!

Confins [MG]

Agosto de 2019 
pela madrugada

o sal na moleira

e o ícone daquela geração

prefere a lama

[soberba

ante à água

com mãos mecânicas regozijam a

daquela serra outonal

[geologia

[em íntimo duelo

arrasto pela lírica-o toldo sangue e a economia

dos seus abismos que predam corações]

senhores - essa sintaxe masculina do poder

o apregoado dos olhos denota

é o favo agudo que estrondas a pedra

os afazeres do grito

[derradeira

o alfazema do jardim e teu pulso

o relicário antigo

a criança que já não podemos ver o gesto

vaga em ordem alfabética um silêncio

chega-gritará os outros?

a estética do ferro desbotou o horizonte

e os cadáveres

implicarão novos dízimos

outras violetas que a nação

[apodrecem

eu beijei

um a um membro efetivo da canga mineral - são os animais que bestializamos

e tornamos sal e estrume esquecidos no objeto industrial.

Brumadinho [MG]

Fevereiro de 2019 
para Alessandra Munduruku

as razões têm púcaro que cada um carrega em voga obstinada

o corpo Indígena

em talheres de prata enfeitam

terra adentro-minas que desaguam tormentas

os apelidos da fantasia - o sermão da mercadoria

o que bendizer do teu olhar luminária - a raça das borboletas

a solidão do búfalo - resinas na filosofia?

o corpo é pedra e voa - vem vamos ouvir tudo pelo progresso - a fada descalça o sofrimento canta

em meu solo de açafrão

o corpo tangido da música

calo a voz pelo infinito da rebelião!

Imperatriz [MA]

8 de setembro de 2019 
para Pedro Carrano

este arremedo de tempo

arde no ar sutilezas - a avó que não tive quando a infância era arrozais costura paciência na gritaria

quase que por nada tilintamos o ovo da serpente

ajoelho no encanto

em tom de dúvida - pequenos segredos são iscas

[famintas!

as lutas calejaram meus camaradas - os que se foram sorrindo

os que suspiram fuligem polindo teorias

eu não duvido a condição humana é lírica-um bilhete arremessado

se me resta olhar a fotografia na parede - penso

em Bernardo se despedindo para ser adulto - a miúda letra do livro manhãs recíprocas entre mãos e alfombras toda modernidade da

[velhice

a dialética perturba o voo da mosca outras obsessões de

[cavaleiros

que o poder levou ao poder

Cidade de São Paulo [SP]

5 de setembro 
com suas plantas - o oxigenismo dos livros cria e faz-me delirar: o objeto válido da vida é a idade

nada receia as rugas - há apenas o sentimento e sua fugaz contenda que os besouros alertam a montanha e seus interstícios - atravessando o todo [perplexo

da sua casa averigua a economia e sabe que os oligarcas sorriem expulsa com a palavra os antípodas porque não há mais a espera contida do uivo do lobo de soleira

com ela eu prefiro o desmantelo da gargalhada em mar prático a nau da insônia-onde pontua a chance dos pássaros.

Charles Trocate Anchieta [ES]

4 de março de 2019 
festejo

no interior dos lugares o relicário que lá existe

a viagem desplanejada como quem não tem coragem de fazê-la amo com um amor trôpego de tudo

e rezo pelos cemitérios

nos olhos do país

os mortos caminham pavilhões de metais

amo com o amor trôpego do mundo

o boi é a soma dos hectares assimilados quando traduzo Valéry

e pela palavra possa despossar currais

Porto Velho [RO]

Abril de 2019

experimentei o início do século já nem sei

as cifras que capitulam o planeta

- a inutilidade do desejo

a fanfarrice dos inimigos a valentia do

[soldado

se tivesse que escolher um outro nome

me chamaria Joaquim Amador!

os iludidos sorrindo outros em luta no final da terceira república algum nervo na labuta - é o ano que não termina nos próximos

Salvador [BA]

Março de 2019 
a chaminé

e briga pela primeira palavra

eu vivo assim-borboleta empoeirada

estes dias que a política é gambiarra e soberba de delfins onde cabe a palavra inteira do jardim?

a emblemática

o pão do privilégio e a faca

a renitência sabe chamar também

lixo de musa

dicionário de medusa

andar no futuro com perna de pau quando tudo for

[dúvida

ensanguentado na peleja

aquela boca antiga ainda beija!

Vitoria [ES]

Fevereiro de 2019 
em Altamira

gargantas cortadas

esta álgebra amazônica é renitente

os lobos enfezados

notícia o jornal antes da

[chuva

os corpos agora deliram a política dos vivos

aquele rio Xingu apoteose dos animais

criou o presídio - as facetas do crime

modernizou a morte!

52 miseráveis vingados pela espera

16 decapitados a resina da velha árvore!

Ribeirão das Neves [MG]

Julho de 2019 
os homens não podem ser empregados

falava o economista inglês

outros animais também não - a psicologia da

[fábrica

objeto de desejo e o pé saltita

- a insana busca dos prazeres

no editorial se combinam a essencialidade dos

[verbos

a vida é uma coleção de inveja reclama

a teoria de auto ajuda e o anúncio da etiqueta

de boa Drummond mandaria nudez pelo mineral do whatsapp?

diria a psicanálise

muito da ecologia da palavra!

Amsterdam, Holanda

Novembro, 2019 
cinco peças de roupas é o meu arsenal confrontado elas me fazem elegante e observado pelo que comento não me nego a usar o colírio

e um a um pondero meus 42 anos em arrepios falando de mim talvez eles entendam o que é o povo os que souberam da viagem não levarei presentes é uma experiência andar pelo mundo cheio de mamutes plastificados devolver aos jardins os sons dos peixes sutis liquidar intrigas

falei alguma coisa de geologia

a pedra ramalhete que querem triturar

Bilbao, País Vasco

Novembro de 2019 